\title{
Genome Relationship among Nine Species of Millettieae (Leguminosae: Papilionoideae) Based on Random Amplified Polymorphic DNA (RAPD)
}

\author{
Laxmikanta Acharya ${ }^{a}$, Arup Kumar Mukherjee ${ }^{\mathrm{b}}$, and Pratap Chandra Panda ${ }^{\mathrm{a}, *}$ \\ a Taxonomy and Conservation Division, Regional Plant Resource Centre, Bhubaneswar \\ 751015, Orissa, India. Fax: +91-674-2550274. E-mail: pcpanda2001@yahoo.co.in \\ b DNA Finger Printing Laboratory, Division of Plant Biotechnology, Regional Plant \\ Resource Centre, Bhubaneswar 751015, Orissa, India \\ * Author for correspondence and reprint requests \\ Z. Naturforsch. 59c, 868-873 (2004); received June 21, 2004
}

Random amplified polymorphic DNA (RAPD) marker was used to establish intergeneric classification and phylogeny of the tribe Millettieae sensu Geesink (1984) (Leguminosae: Papilionoideae) and to assess genetic relationship between 9 constituent species belonging to 5 traditionally recognized genera under the tribe. DNA from pooled leaf samples was isolated and RAPD analysis performed using 25 decamer primers. The genetic similarities were derived from the dendrogram constructed by the pooled RAPD data using a similarity index, which supported clear grouping of species under their respective genera, inter- and intra-generic classification and phylogeny and also merger of Pongamia with Millettia. Elevation of Tephrosia purpurea var. pumila to the rank of a species (T. pumila) based on morphological characteristics is also supported through this study of molecular markers.

Key words: Genome Relationship, RAPD, Millettieae

\section{Introduction}

Leguminosae (Fabaceae) is one of the largest families of flowering plants, comprising over 650 genera and 18,000 species (Polhill, 1981). The family is economically very important being the major source of food and forage and its great diversity (the third largest family in flowering plants) also has attracted much interest in ecological as well as systematic studies. The predominantly tropical tribe Millettieae, consisting of over 40 genera and nearly 1,000 species, is generally thought to have given rise to many temperate herbaceous groups and several tropical tribes of papilionoid legumes, such as Phaseoleae, Indigofereae, Galegeae and their allies (Polhill, 1981; Geesink, 1984) and is considered to be one of the most problematic groups in legume systematics. This tribe is generally defined as those tropical woody papilionoids with some derived flower features (fused keel petals) and seeds containing non-protein amino acids but there are many exceptions (Evans et al., 1985). The paraphyly of Millettieae has been suggested in many studies based on morphological characters (Geesink, 1984; Zandee and Geesink, 1987), biochemical (Evans et al., 1985), molecular (Bruneau et al., 1994; Lavin et al., 1998; $\mathrm{Hu}$ et al., 2000) and cytological data (Goldblatt, 1981).
The tribe is traditionally divided into three subgroups, with Tephrosia, Millettia and Derris as the major components in each (Geesink, 1984). Derris and allies (e.g., Lonchocarpus) have been placed in the tribe Dalbergieae because of indehiscent pods (Bentham, 1860). Millettia and Tephrosia, with dehiscent pods, were separated from Derris and Lonchocarpus and placed within the broadly circumscribed tribe Galegeae (Bentham, 1865) or in the more narrowly circumscribed tribe Tephrosieae (Gillett 1971). As suggested by Geesink (1981), the structural differences between an indehiscent and dehiscent pod is not morphologically based, transitions do occur, and a classification based upon pod shapes is certainly more complicated with the present state of knowledge of this group than a simple division into dehiscent and indehiscent. He established Millettieae (formerly Tephrosieae s.l.) and included all the genera mentioned above.

Several molecular markers have been widely used to assess the genetic diversity and study of phylogenies in a number of legume taxa like $A c a$ cia (Casiva et al., 2002), Afgekia (Prathepha and Baimai, 2003), Astragalus (Sanderson and Liston, 1995), Atylosia-Cajanus complex (Parani et al., 2000), Lathyrus (Asmussen and Liston, 1998), Lotus (Campos et al., 1994), Medicago (Bena et al., 
1998), Phaseoleae (Bruneau et al., 1994) and Wisteria and Callerya (Liston, 1995). The molecular phylogeny of Millettieae has been reviewed and analyzed by $\mathrm{Hu}$ et al. (2000).

In order to authenticate the existing classification and phylogeny of the Indian members of the tribe Millettieae based on taxonomic evidences, to circumscribe certain problematic genera and to establish the taxonomic status of some infra-specific categories in Tephrosia, an attempt was made to characterize 9 representative species of the tribe belonging to 5 traditionally recognized genera by RAPD marker.

\section{Materials and Methods}

\section{Plant material}

Seeds of three species of Tephrosia, two species of Derris, two species of Milletia and one species each of Pongamia and Piscidia were collected from the garden of Regional Plant Resource Centre, Bhubaneswar and different forest areas of Orissa, India and plants were raised in the nursery for collection of samples for the present study. The correct botanical names with author citation, synonym(s), habit, flowering and fruiting time, collection locality with field numbers etc. are given in Table I. The voucher herbarium specimens are deposited in the Herbarium of Regional Plant Resource Centre, Bhubaneswar, Orissa, India. Very tender and healthy leaves were taken for isolation of genomic DNA.

\section{Genomic DNA isolation}

DNA was isolated from young and freshly collected leaves using the CTAB method as described by Saghai-Maroof et al. (1984). RNA was removed by giving RNaseA treatment (@60 $\mu \mathrm{g}$ for $1 \mathrm{ml}$ of crude DNA solution at $37^{\circ} \mathrm{C}$ ) followed by two washes with phenol/chloroform/isoamylalcohol (25:24:1) and subsequently two washes with chloroform/isoamylalcohol (24:1). After centrifugation, the upper aqueous phase was separated, 1/10 volume $3 \mathrm{~m}$ sodium acetate $(\mathrm{pH} 4.8)$ was added and DNA was precipitated with 2.5 volume of prechilled absolute ethanol. DNA was dried and dissolved in $\mathrm{T}_{10} \mathrm{E}_{1}$ buffer (Tris- $\mathrm{HCl} 10 \mathrm{~mm}$, EDTA $1 \mathrm{~mm}, \mathrm{pH} 8$ ). Quantification was made by running the dissolved DNA in $0.8 \%$ agarose gel along side uncut $\lambda$ DNA of known concentration. The DNA was diluted to $25 \mathrm{ng}$ per $\mu \mathrm{l}$ for RAPD analysis.

Table I. Botanical names, synonym(s), habit, flowering/fruiting time and collection locality and field numbers of 9 species of the tribe Millettieae.

\begin{tabular}{|c|c|c|}
\hline Name of the species & Habit & Locality with field collection number \\
\hline $\begin{array}{l}\text { Tephrosia pumila (Lam.) Pers. } \\
\text { [T. purpurea (L.) Pers. var. pumila } \\
\text { (Lam.) Baker] }\end{array}$ & Undershrub & $\begin{array}{l}\text { Utkal Univ. campus, Bhubaneswar, Orissa, } \\
\text { LKA }-2795\end{array}$ \\
\hline Tephrosia purpurea (L.) Pers. & Undershrub & $\begin{array}{l}\text { Regional Plant Resource Centre, } \\
\text { Bhubaneswar, Orissa, LKA - } 13 \text {. }\end{array}$ \\
\hline $\begin{array}{l}\text { Tephrosia villosa (L.) Pers. } \\
\text { (T. hirta Buch.-Ham.) }\end{array}$ & Undershrub & $\begin{array}{l}\text { Regional Plant Resource Centre, } \\
\text { Bhubaneswar, Orissa, LKA - } 2531\end{array}$ \\
\hline $\begin{array}{l}\text { Derris trifoliata Lour. } \\
\text { [D. uliginosa (Willd.) Benth.] }\end{array}$ & Climber & $\begin{array}{l}\text { Bhitarkanika Mangrove Forests, Orissa, } \\
\text { LKA - } 2523\end{array}$ \\
\hline Derris scandens (Roxb.) Benth. & Climber & $\begin{array}{l}\text { Khandagiri hills, Bhubaneswar, Orissa, } \\
\text { LKA - } 6176\end{array}$ \\
\hline $\begin{array}{l}\text { Millettia peguensis Ali } \\
\text { (M. ovalifolia Kurz) }\end{array}$ & Small tree & $\begin{array}{l}\text { Regional Plant Resource Centre, } \\
\text { Bhubaneswar, Orissa, LKA }-6178\end{array}$ \\
\hline Millettia racemosa (Roxb.) Benth. & Woody climber & $\begin{array}{l}\text { Khandagiri hills, Bhubaneswar, Orissa, } \\
\text { LKA }-830\end{array}$ \\
\hline $\begin{array}{l}\text { Millettia pinnata (L.) Geesink } \\
{[\text { Pongamia pinnata (L.) Pierre.] }} \\
{[\text { Derris indica (Lam.) Bennet] }}\end{array}$ & Small tree & $\begin{array}{l}\text { Regional Plant Resource Centre, } \\
\text { Bhubaneswar, Orissa, LKA - } 3440\end{array}$ \\
\hline $\begin{array}{l}\text { Piscidia piscipula }(\mathrm{L} .) \text { Sargent } \\
{[P . \text { erythrina }(\mathrm{L} .)]}\end{array}$ & Tree & $\begin{array}{l}\text { Regional Plant Resource Centre, } \\
\text { Bhubaneswar, Orissa, LKA - } 6177\end{array}$ \\
\hline
\end{tabular}




\section{RAPD analysis}

For RAPD analysis, PCR amplification of $25 \mathrm{ng}$ of genomic DNA was carried out using standard 18 decamer oligonucleotide primers, i.e. OPA02, OPA03, OPA10, OPD02, OPD03, OPD07, OPD08, OPD18, OPD20, OPN04, OPN05, OPN06, OPN07, OPN08, OPN10, OPN11, OPN15 and OPN16 (Operon Technologies, Alameda, USA). The RAPD analysis was performed as per the standard methods of Williams et al. (1990). Each amplification reaction mixture of $25 \mu \mathrm{l}$ contained $20 \mathrm{ng}$ of template DNA, $2.5 \mu \mathrm{l}$ of $10 \mathrm{X}$ assay buffer $(100 \mathrm{~mm}$ Tris- $\mathrm{HCl}, \mathrm{pH} 8.3,0.5 \mathrm{M} \mathrm{KCl}$ and $0.01 \%$ gelatin), $1.5 \mathrm{~mm} \mathrm{MgCl}_{2}, 200 \mu \mathrm{M}$ each of dNTPs, $20 \mathrm{ng}$ of primer and $0.5 \mathrm{U}$ Taq DNA polymerase (Bangalore Genei Pvt. Ltd., Bangalore, India). The amplification was carried out in a thermal cycler (Perkin Elmer, Model 2400, USA). The first cycle consisted of denaturation of template DNA at $94{ }^{\circ} \mathrm{C}$ for $5 \mathrm{~min}$, primer annealing at $37^{\circ} \mathrm{C}$ for $1 \mathrm{~min}$ and primer extension at $72^{\circ} \mathrm{C}$ for $2 \mathrm{~min}$. In the subsequent 42 cycles the period of denaturation was reduced to $1 \mathrm{~min}$ while the primer annealing and primer extension time was maintained same as in the first cycle. The last cycle consisted of only primer extension at $72{ }^{\circ} \mathrm{C}$ for $7 \mathrm{~min}$. PCR products were separated on a $1.5 \%$ agarose gel containing ethidium bromide solution (@ $0.5 \mu \mathrm{g} / \mathrm{ml}$ of gel solution). The size of the amplicons was determined using size standards (100 bp ladder plus; MBI Fermentas, Lithuania). DNA fragments were visualized under UV light and photographed.

\section{Data analysis}

The presence/absence of bands in RAPD analysis was recorded in binary $(0,1)$ form. All the bands (polymorphic and monomorphic) were taken into account for calculation of similarity with a view to avoid over/underestimation of the distance (Gherardi et al., 1998). Jaccard's coefficient of similarity (Jaccard, 1908) was measured and a dendrogram based on similarity coefficients generated by the un-weighted pair group method using arithmetic averages (UPGMA) (Sneath and Sokal, 1973) and SHAN clustering. All the analyses were done by using the computer package NTSYS-PC (Rohlf, 1997).

\section{Results}

Nine species of the tribe Millettieae were fingerprinted with 25 RAPD primers out of which only 18 produced reproducible and scorable bands. The details of the primers producing scorable bands, their nucleotide sequence, number of amplicons, number of polymorphic/monomorphic bands,

Table II. RAPD data of nine species of Millettieae using 16 random primers.

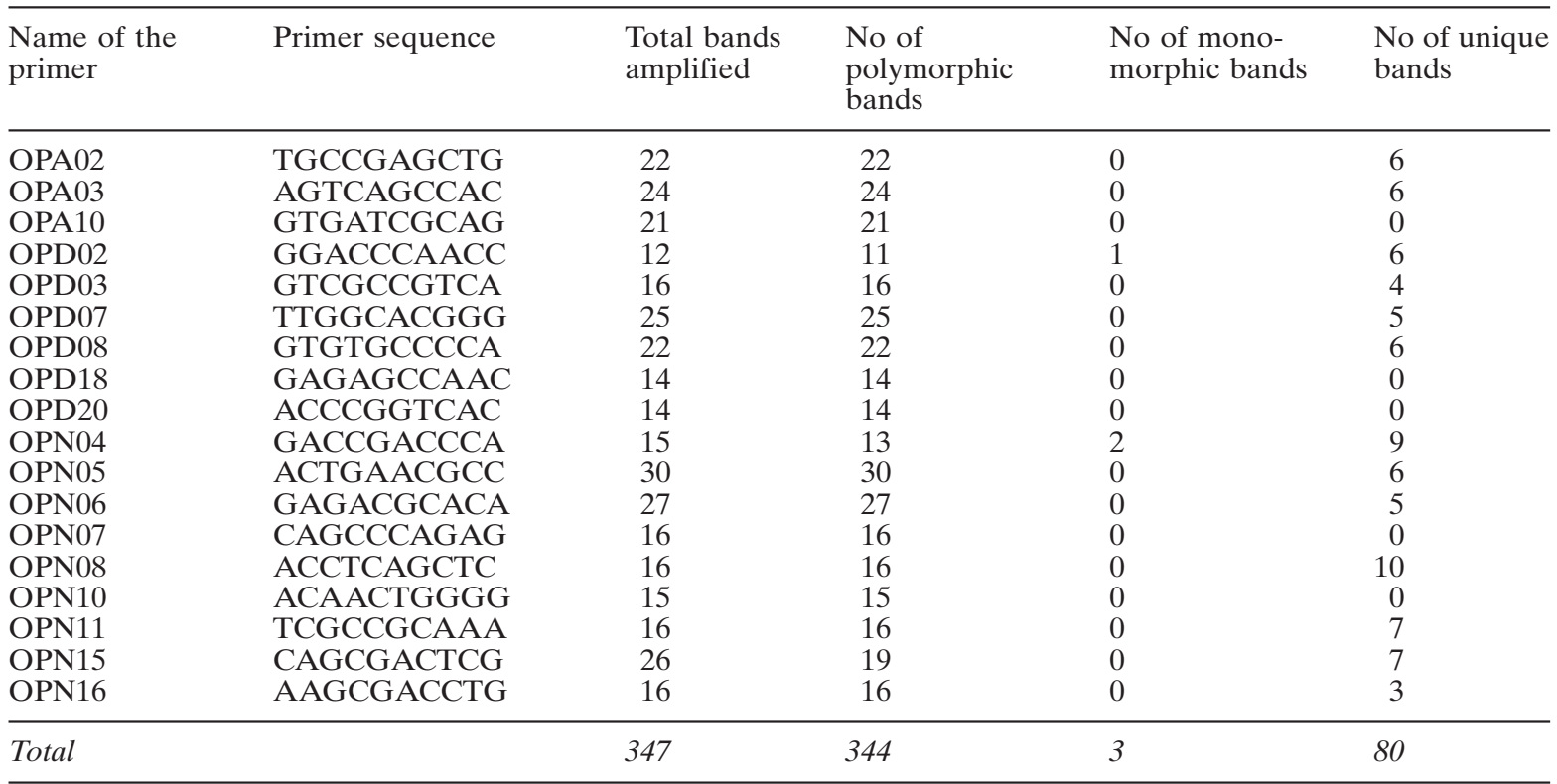




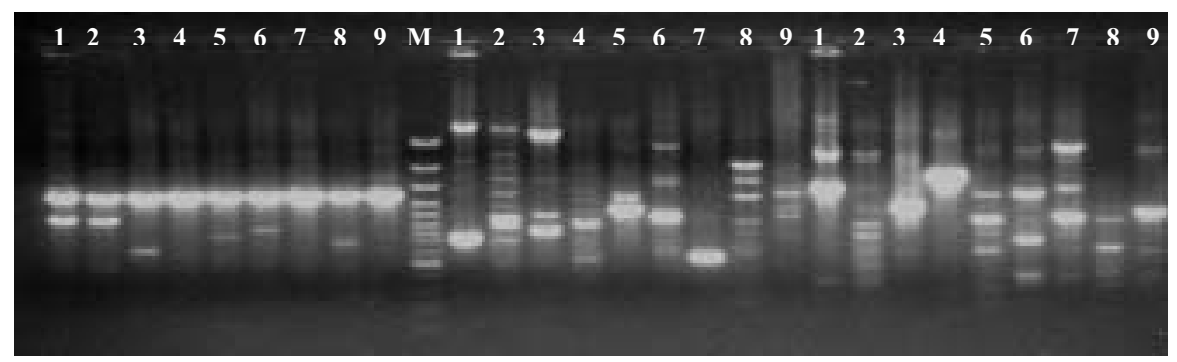

Fig. 1. RAPD pattern of 9 species of Millettieae using OPN04, OPN05, OPN06. M = $100 \mathrm{bp}$ ladder plus (MBI Fermantus, Lithuania); lane 1 to 9 are Tephrosia pumila, Tephrosia purpurea, Tephrosia villosa, Derris trifoliata, Derris scandens, Millettia peguensis, Millettia racemosa, Pongamia pinnata, Piscidia piscipula, respectively.

number of unique bands and the range of amplified fragments are presented in Table II. Out of the total number of 347 bands amplified, 344 were polymorphic and 3 were monomorphic bands. The maximum number of amplicons was observed in primer OPN05 (30) and least in case of primer OPD02 (12). In OPD02 and OPN04, one and three monomorphic bands were detected, respectively. The RAPD banding pattern in 9 species of the tribe Millettieae using primer OPN04, OPN05 and OPN06 is presented in Fig. 1.

The dendrogram constructed on the basis of RAPD data showed two major clusters in the tribe (Fig. 2). The genus Tephrosia with three species namely Tephrosia pumila, T. purpurea and T. villosa formed a distinct clad and the other members of the remaining genera Derris, Millettia, Pongamia and Piscidia were grouped under the second cluster. There were two nodes in the second clad

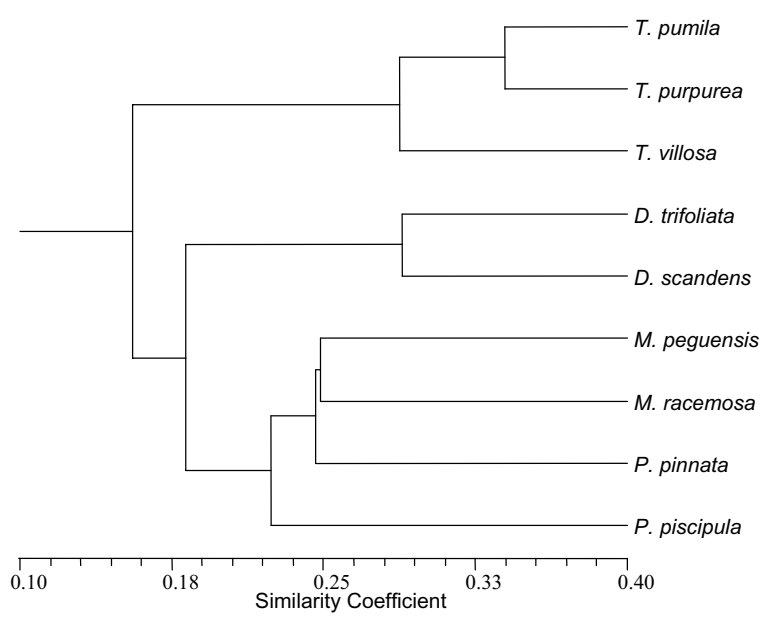

Fig. 2. Dendrogram showing the genomic relationship among 9 species of Millettieae using RAPD marker. formed by the above 4 genera. While the first node is shared by the two species of Derris (D. scandens and $D$. trifoliata), the second node is comprised of two species of Millettia ( $M$. peguensis and $M$. racemosa) and the lone species of Pongamia ( $P$. pinnata). Piscidia piscipula also shared a node with the Millettia-Pongamia group at an approximately $22.6 \%$ level of similarity. Interestingly, the monotypic genus Pongamia shared a node with the species of Millettia at a $24.83 \%$ level of similarity exhibiting close genetic similarity with it.

\section{Discussion}

Hu et al. (2000) reconstructed phylogenetic relationships in the tribe Millettieae and allies from chloroplast $\operatorname{trn} \mathrm{K} / \mathrm{mat} K$ sequences and recognized a well-supported "core Millettieae" clade comprising the 4 large genera Millettia, Lonchocarpus, Derris and Tephrosia. Among the core-Millettieae taxa, the genus Tephrosia formed a separate clade distantly placed from the second clade comprising of genera Piscidia, Millettia, Lonchocarpus, Derris and others. In the latter group, Piscidia was also singled out leaving Millettia, Lonchocarpus, Derris etc. to form a cluster. Our findings based on RAPD analysis are in conformity with the observations of $\mathrm{Hu}$ et al. (2000).

The genus Pongamia exhibited close genetic similarity with Millettia and shared a node at a $24.83 \%$ level of similarity. This justifies merger of the genus Pongamia with Millettia on morphological grounds as suggested by Geesink (1984). The merger of the genus Pongamia with Derris and subsequent transfer of Pongamia pinnata to Derris (Bennet, 1972) are not tenable and even not supported by taxonomic evidences.

Baker (1876) reduced Tephrosia pumila (Lam.) Pers. (= Galega pumila Lam.) to a variety under 
the widespread T. purpurea (L.) Pers., and named it as T. purpurea (L.) Pers. var. pumila (Lam.) Baker. T. pumila differs from T. purpurea in its procumbent habit, villous stems, $1-3$ flowered racemes, larger red flowers, sub-apical strophiole on the seeds and several other morphological characters. With so much morphological variations, the former taxon deserves the status of a species and not merely an intra-specific category under T. purpurea as has been conceived by many subsequent workers. In conjunction, molecular data obtained during the present study on the basis of RAPD analysis also revealed that the 2 taxa exhibit only

Asmussen C. B. and Liston A. (1998), Chloroplast DNA characters, phylogeny, and classification of Lathyrus (Fabaceae). Am. J. Bot. 85, 87-401.

Baker J. G. (1876), Leguminosae. In: Flora of British India, vol. 2 (Hooker J. D., ed.). L. Reeve and Co., London, U.K., pp. 56-306.

Bena G., Jubier M. F., Olivieri I., and Lejeune B. (1998), Ribosomal external and internal transcribed spacers: Combined use in the phylogenetic analysis of Medicago (Leguminosae). J. Mol. Evol. 46, 299-306.

Bennet S. S. R. (1972), The taxonomic status of the genus Pongamia Vent. J. Bombay Nat. Hist. Soc. 68, 302-303.

Bentham G. (1860), A Synopsis of the Dalbergieae. J. Lin. Soc. Bot. 4 (Suppl.), 1-134.

Bentham G. (1865), Leguminosae. In: Genera Plantarum (Bentham G. and Hooker J. D., eds.). Reeve \& Co., London, U.K., pp. 434-600.

Bruneau A., Doyle J. J., and Doyle J. A. (1994), Phylogenetic relationships in Phaseoleae: evidence from chloroplast DNA restriction site characters. In: Advances in Legume Systematics, part 7, Phylogeny (Crisp M. and Doyle J. J., eds.). Royal Botanic Gardens, Kew, U.K., pp. 309-330.

Campos L. P., Raelson J. V., and Grant W. F. (1994), Genome relationship among Lotus species based on random amplified polymorphic DNA (RAPD). Theor. Appl. Genet. 88, 417-422.

Casiva P. V., Saidman B. O., Vilardi V. C., and Cialdella A. M. (2002), First comparative phenetic studies of Argentinean species of Acacia (Fabaceae) using morphometric, isozymal, and RAPD approaches. Am. J. Bot. 89, 843-853.

Evans S. V., Fellows L. E., and Bell E. A. (1985), Distribution and systematic significance of basic non-protein amino acids and amines in the Tephrosieae. Biochem. Syst. Ecol. 13, 271-302.

Geesink R. (1981), Tephrosieae. In: Advances in Legume Systematics, part 1 (Polhill M. and Raven P. H., eds). Royal Botanic Gardens, Kew, U.K., pp. 245-260.
$38 \%$ genetic similarity and are thus distantly related. It appears, therefore, logical to treat T. pumila as a distinct species distinguishable from T. purpurea by a number of well-defined and consistent characters.

\section{Acknowledgements}

The authors wish to thank Ms Liz Keyser, Royal Botanic Gardens, Kew, U. K. for providing relevant literature on taxonomy of the tribe Millettieae and the Department of Forest and Environment, Government of Orissa for financial assistance.
Geesink R. (1984), Scala Millettiearum: A Survey of the Genera of the Tribe Millettieae (Leguminosae-Papilionoideae) with methodological considerations. E. J. Brill/Leiden University Press, Leiden.

Gherardi M., Mangin B., Goffinet B., Bonnet D., and Huguet T. (1998), A method to measure genetic distance between allogamous populations of alfalfa (Medicago sativa) using RAPD molecular marker. Theor. Appl. Genet. 98, 406-412.

Gillett J. B. (1971), Tephrosieae. In: Flora of Tropical East Africa, Leguminosae, part 3: Subfamily Papilionoideae (1) (Milne-Readhead E. and Polhill R. M., eds.). Crown Agents, London, U.K.

Goldblatt P. (1981), Cytology and phylogeny of Leguminosae. In: Advances in Legume Systematics, part 2 (Polhill R. M. and Raven P. H., eds.). Royal Botanic Gardens, Kew, U.K., pp. 427-463.

Hu J.-M., Lavin M., Wojciechowski M. F., and Sanderson M. J. (2000), Phylogenetic systematics of the tribe Millettieae (Leguminosae) based on chloroplast trnK/ mat $K$ sequences and its implications for evolutionary patterns in Papilionoideae. Am. J. Bot. 87, 418-430.

Jaccard P. (1908), Nouvelles recherches sur la distribution florale. Bull. Soc. Vaudoise des Sci. Nat. 44, 223-270.

Lavin M., Eshbaugh E., Hu, J.-M., Matthews S., and Sharrock R. A. (1998), Monophyletic subgroups of the tribe Millettieae (Leguminosae) as revealed by phytochrome nucleotide sequence data. Am. J. Bot. 85, $412-433$.

Liston A. (1995), Use of polymerase chain reaction to survey for the loss of inverted repeat in the legume chloroplast genome. In: Advances in Legume Systematics, part 7, Phylogeny (Crisp M. and Doyle J. J., eds.). Royal Botanic Gardens, Kew, U. K., pp. 3140.

Parani M., Lakshmi M., Senthil Kumar P., and Parida A. (2000), Ribosomal DNA variation and phylogenetic relationships among Cajanus cajan (L.) Millsp., and its wild relatives. Cur. Sci. 78, 1235-1238. 
Polhill R. M. (1981), Papilionoideae. In: Advances in legume systematics, part 1 (Polhill R. M. and Raven P. H., eds.). Royal Botanic Gardens, Kew, U.K., pp. 191-208.

Prathepha P. and Baimai V. (2003), Molecular characterization of the divergence of rare species of the genus Afgekia (Papilionoideae, tribe Tephrosieae) by RAPD markers and nucleotide sequence analysis. Sci. Asia 29, 13-20.

Rohlf F. J. (1997), NTSYS-pc Numerical Taxonomy and Multivariate Analysis System. Exeter Software, Setauket, New York, USA.

Saghai-Maroof M. A., Soliman K. M., Jorenson R. A., and Allard R. W. (1984), Ribosomal DNA spacer length polymorphism in barley: Mendelian inheritance, chromosomal location and population dynamics. Proc. Natl. Acad. Sci. USA 81, 8014-8018.
Sanderson M. J. and Liston A. (1995), Molecular phylogenetic systematics of Galegeae, with special reference to Astragalus. In: Advances in Legume Systematics, part 7, Phylogeny (Crisp M. and Doyle J. J., eds.). Royal Botanic Gardens, Kew, U.K., pp.331350.

Sneath P. H. A. and Sokal R. R. (1973), Numerical Taxonomy. W. H. Freeman and Company, San Francisco, California, USA.

Williams J. G. K., Kubelik A. R., Livak K. J., Rafalski J. A., and Tingey S. V. (1990), DNA polymorphisms amplified by arbitrary primers are useful as genetic markers. Nucl. Aci. Res. 18, 6531-6535.

Zandee M. and Geesink R. (1987), Phylogenetics and legumes: a desire for the impossible. In: Advances in Legume Systematics, part 3 (Stirton C. H., ed.). Royal Botanic Gardens, Kew, U.K., pp. 131-167. 